\title{
Preparation of Some Substituted Terephthalic Acids
}

\author{
Susanna Branion and Vladimir Benin \\ Department of Chemistry, University of Dayton, Dayton, Ohio, USA
}

\begin{abstract}
We report in detail the preparation of two substituted terephthalic acids: 2-sulfomethylterephthalic acid (1) and 2-phosphonoterephthalic acid (2). Efficient, short syntheses have been developed for both compounds. They are potentially useful monomers for construction of acid-pendant polymer chains.
\end{abstract}

Keywords: Acid-pendant polymers, arenephosphonic acids, arenesulfonic acids, terephthalic acids

\section{INTRODUCTION}

Substituted terephthalic acids, with pendant acidic functional group, have found increasing application in recent years. The best-known example among them is 2-sulfoterephthalic acid, which has been employed in the preparation of rigid-rod polymers, ${ }^{[1,2]}$ polymers with enhanced solubility, ${ }^{[3]}$ dopants for electrically conductive polymers, ${ }^{[4]}$ and enzyme inhibitors for glaucoma treatment. ${ }^{[5]}$

Our recent attempts at preparation of sulfonic acid-pendant poly(benzimidazole) (SPBI) demonstrated that conducting the polymerization at elevated temperatures, necessary for satisfactory chain length, triggers an adverse process of desulfonation and an accompanying loss of solubility of the resultant polymer. Consequently, we focused our attention on the preparation and employment of alternative acidic group-containing monomers. The current report details our efforts to synthesize and characterize two particular

Received in the USA January 23, 2006

Address correspondence to Vladimir Benin, Department of Chemistry, University of Dayton, 300 College Drive, Dayton, OH 45469-2357, USA. Tel.: 937-229-4762; Fax: 937-229-2635; E-mail: vladimir.benin@ notes.udayton.edu 
compounds: 2-sulfomethylterephthalic acid (1) and 2-phosphonoterephthalic acid (2) (Scheme 1). The former is a new compound, whose synthesis and characterization we report for the first time, whereas 2-phosphonoterephthalic acid has been previously reported in two patent sources from $1998{ }^{[6,7]}$ For reasons stated later, we found it necessary to develop a new synthetic protocol for the preparation of $\mathbf{2}$, which is described in the current report.

\section{RESULTS AND DISCUSSION}

\section{Preparation of 2-Sulfomethylterephthalic Acid (1)}

The synthetic sequence employed in the preparation of compound $\mathbf{1}$ is shown in Scheme 2. The challenge in the preparation of this material comes from the fact that of the three $\mathrm{C}$-atoms connected to the benzene ring, two are in the form of carboxylic acid functional groups, and the third one is a benzylic type carbon (i.e., the third center has a different degree of oxidation). Therefore the carboxyl groups have to be introduced in the molecule as such, rather than being generated at a later stage. The preparation starts, therefore, with the dilithiation of 2,5-dibromotoluene with $t$-BuLi at $-78{ }^{\circ} \mathrm{C}$, followed by reaction with dry ice and subsequent acidification, leading to the introduction of the two carboxyl groups. ${ }^{[8]}$ The resultant 2-methylterephthalic acid (3) is esterified, ${ }^{[9]}$ then side-chain brominated with NBS, to produce dimethyl 2-bromomethylterephthalate (4). ${ }^{[9,10]}$ Compound 4 is then subjected to treatment with aqueous $\mathrm{Na}_{2} \mathrm{SO}_{3}$, in the presence of $\mathrm{Bu}_{4} \mathrm{NBr}$ as catalyst, in a process of nucleophilic replacement of bromine by a sulfonate anion. ${ }^{[11]}$ The resultant sodium salt $\mathbf{5}$ is treated with conc. $\mathrm{HCl}$ to yield the target acid $\mathbf{1}$.

\section{Prepration of 2-Phosphonoterephtahlic Acid (2)}

In previously published patent literature the preparation of $\mathbf{2}$ is described, following two different methods. Method 1 relies on the introduction of a phosphorus-containing moiety into the aromatic ring via aromatic electrophilic substitution process involving $p$-xylene and thiophosphoryl trichloride,<smiles>O=C(O)c1ccc(C(=O)O)c(CS(=O)(=O)O)c1</smiles>

1<smiles>O=C(O)c1ccc(C(=O)O)c(P(=O)(O)O)c1</smiles>

2

Scheme 1. 


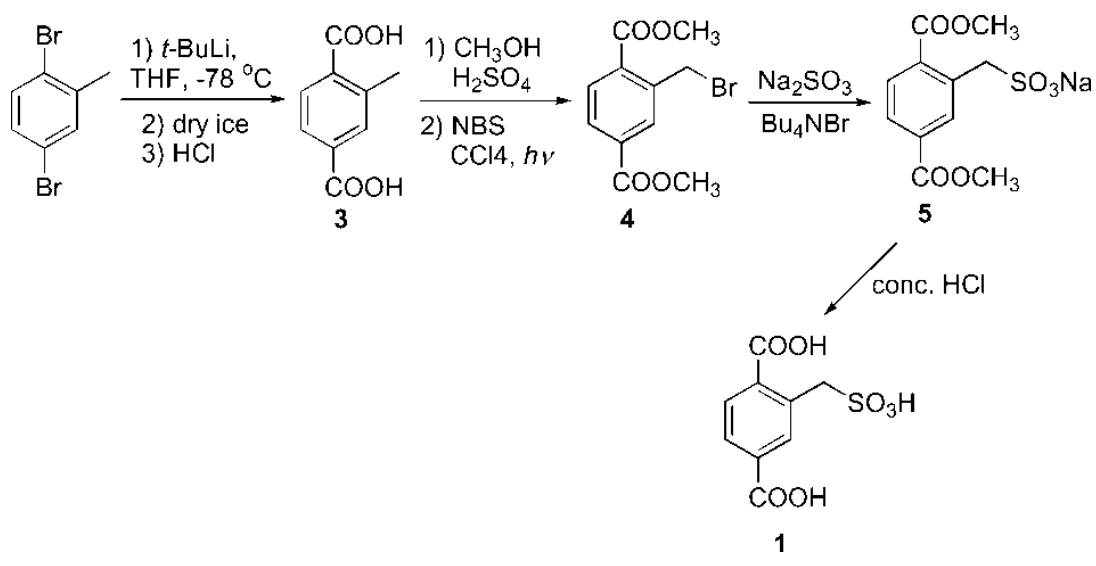

Scheme 2.

followed by acid hydrolysis of the resultant 2,5-dimethylbenzenephosphonothioic dichloride and a high-pressure Co-catalyzed oxidation in an autoclave of 2,5-dimethylphosphonic acid. ${ }^{[7]}$ Such a method is inherently complicated and difficult to apply in laboratory conditions, because of the character of the necessary equipment. Method 2 employs palladium- or nickel-catalyzed coupling of dimethyl 2-bromoterephthalate and triethyl phosphite, followed by acid hydrolysis. ${ }^{[6]}$ Our repeated attempts to reproduce the latter chemistry led invariably to full recovery of the starting material. Hence we undertook the development of a new synthetic sequence, which would be easily applied in laboratory conditions, with reproducible results. The synthesis is presented in Scheme 3 and is based on the intermediate preparation of diethyl 2,5-dimethylbenzenephosphonate (6). Earlier preparations of $\mathbf{6},{ }^{[12,13]}$ described in literature, rely on the introduction of the phosphonate ester substructure via oxidative coupling of $p$-xylene with triethylphosphite or diethylphosphite. This methodology, however, requires substantial amounts of the relatively costly silver nitrate and also leads to generation of polyphosphonated species, as well as arene self-coupling byproducts. We found that compound $\mathbf{6}$ could be conveniently prepared from 2-bromo-p-xylene. ${ }^{[14]}$ The latter can be either converted to the corresponding

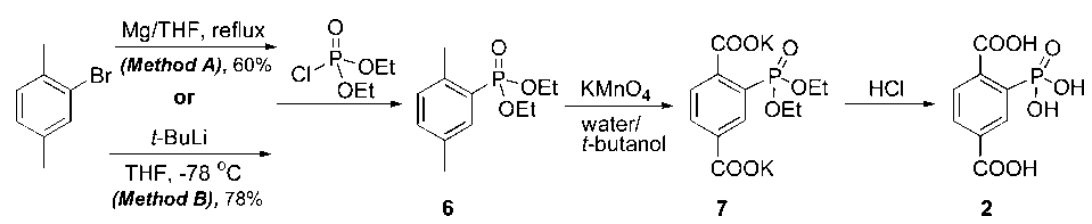

Scheme 3. 
Grignard reagent (method A) or lithiated derivative (method B), followed by reaction of the corresponding organometallic intermediate with diethyl chlorophosphate. Compound $\mathbf{6}$, upon oxidation with $\mathrm{KMnO}_{4}$, yields the dipotassium salt of 2-(diethylphosphonyl)terephthalic acid (7). Salt $\mathbf{7}$ is treated with conc. $\mathrm{HCl}$ to yield the target compound $\mathbf{2}$.

\section{CONCLUSIONS}

In this work we have reported the preparation and characterization of two 2-substituted terephthalic acids, compounds $\mathbf{1}$ and $\mathbf{2}$, which are potentially useful in the construction of functionalized polymer chains.

\section{EXPERIMENTAL}

${ }^{1} \mathrm{H}$ and ${ }^{13} \mathrm{C}$ spectra of intermediate and target compounds were recorded at $300 \mathrm{MHz}$ and $75 \mathrm{MHz}$ respectively and referenced to the solvent $\left(\mathrm{CDCl}_{3}\right.$ : $7.27 \mathrm{ppm}$ and $77.0 \mathrm{ppm} ;$ DMSO- $d_{6}: 2.49 \mathrm{ppm}$ and $39.5 \mathrm{ppm} ; \mathrm{D}_{2} \mathrm{O}$ : $4.76 \mathrm{ppm}) .{ }^{31} \mathrm{P}$ NMR signals were indirectly referenced to $85 \%$ phosphoric acid $(\delta=0.0 \mathrm{ppm})$ via direct reference to $\mathrm{P}\left(\mathrm{OCH}_{3}\right)_{3}$ as an internal standard $\left(\delta=+141 \mathrm{ppm}\right.$ relative to $\left.85 \% \mathrm{H}_{3} \mathrm{PO}_{4}\right)$. Elemental analysis was provided by Atlantic Microlab, Norcross, GA. HRMS data was provided by the Mass Spectrometry and Proteomics facility at the Ohio State University. 2,5-Dibromotoluene was purchased from the Aldrich Chemical Co. Compounds 3 and 4 were prepared following previously published procedures. ${ }^{[9]}$ Compound $\mathbf{6}$, although previously reported, ${ }^{[12,13]}$ was prepared following a new approach. Hence its synthesis and spectral data are reported in detail.

\section{2-(Sulfomethyl)terephthalic Acid (1)}

An aqueous solution of tetrabutylammonium bromide $(0.008 \mathrm{~g}, 0.025 \mathrm{mmol}$ in $4 \mathrm{~mL}$ of water) was added to a round-bottom flask containing dimethyl 2-bromomethylterephthalate $(0.28 \mathrm{~g}, \quad 0.98 \mathrm{mmol}), \mathrm{Na}_{2} \mathrm{SO}_{3} \quad(0.15 \mathrm{~g}$, $1.15 \mathrm{mmol})$, and ethanol $(4 \mathrm{~mL})$. The resultant mixture was stirred at reflux for $12 \mathrm{~h}$ and cooled to ambient temperature, and the solvent was removed under reduced pressure. Methylene chloride $(10 \mathrm{~mL})$ was added to the residual solid; the mixture was stirred for $15 \mathrm{~min}$ and then vacuum filtered. The solid was washed with methylene chloride and dried to yield the sodium salt 5 as white crystalline compound $(0.20 \mathrm{~g}, 67 \%) .{ }^{1} \mathrm{H}$ NMR $\left(\mathrm{D}_{2} \mathrm{O}\right) \delta 3.90(\mathrm{~s}, 3 \mathrm{H}), 3.91(\mathrm{~s}, 3 \mathrm{H}), 4.64(\mathrm{~s}, 2 \mathrm{H}), 7.89(\mathrm{~d}, J=8.8 \mathrm{~Hz}, 1 \mathrm{H})$, 8.01-8.04 (m, 2H). Sodium salt $5(0.20 \mathrm{~g}, 0.64 \mathrm{mmol})$ was added to $4.0 \mathrm{~mL}$ of concentrated hydrochloric acid, and the resultant mixture was stirred at reflux for $12 \mathrm{~h}$. The mixture was then cooled to ambient 
temperature and left in a refrigerator for $18 \mathrm{~h}$. The solid was vacuum filtered and dried in a drying pistol $\left(60^{\circ} \mathrm{C}\right.$ at $1 \mathrm{~mm} \mathrm{Hg}$ for $\left.12 \mathrm{~h}\right)$ to yield $0.17 \mathrm{~g}(98 \%)$ of acid 1. Mp $290-292{ }^{\circ} \mathrm{C} .{ }^{1} \mathrm{H}$ NMR $\left(\mathrm{D}_{2} \mathrm{O}\right) \delta 4.66(\mathrm{~s}, 2 \mathrm{H}), 7.91$ $(\mathrm{d}, J=8.0 \mathrm{~Hz}, 1 \mathrm{H}), 8.00-8.04(\mathrm{~m}, 2 \mathrm{H}) ;{ }^{1} \mathrm{H}$ NMR (DMSO- $\left.d_{6}\right) \delta 4.26$ $(\mathrm{s}, 2 \mathrm{H}), 7.72(\mathrm{~d}, J=8.1 \mathrm{~Hz}, 1 \mathrm{H}), 7.84\left(\mathrm{dd}, J_{1}=8.1 \mathrm{~Hz}, J_{2}=1.8 \mathrm{~Hz}, 1 \mathrm{H}\right)$, $7.97(\mathrm{~d}, J=1.8 \mathrm{~Hz}, 1 \mathrm{H}) ;{ }^{13} \mathrm{C}$ NMR $\left(\right.$ DMSO- $\left.d_{6}\right) \delta 54.1,127.2,129.6$, 132.2, 133.4, 134.7, 136.7, 166.8, 168.6. HRMS $\left(\mathrm{FAB}^{+}\right) \mathrm{m} / z$ calcd. for $\mathrm{C}_{9} \mathrm{H}_{8} \mathrm{O}_{7} \mathrm{~S} \quad[\mathrm{M}+\mathrm{Na}]^{+}$282.9888, found 282.9893. Anal. calcd. for $\mathrm{C}_{9} \mathrm{H}_{8} \mathrm{O}_{7} \mathrm{~S} \cdot \mathrm{H}_{2} \mathrm{O}: \mathrm{C}, 38.85 ; \mathrm{H}, 3.62 ; \mathrm{S}, 11.52$. Found: $\mathrm{C}, 38.71 ; \mathrm{H}, 3.72$; $\mathrm{S}, 11.38$.

\section{Diethyl 2,5-Dimethylbenzenephosphonate (6)}

\section{Method A}

A suspension of $\mathrm{Mg}(1.42 \mathrm{~g}, 58.42 \mathrm{mmol})$ in anhydrous THF $(100 \mathrm{~mL})$ was brought to reflux. Several drops of 1,2-dibromoethane were added, followed by dropwise addition of 2-bromo-p-xylene $(9.01 \mathrm{~g}, 48.68 \mathrm{mmol}, 6.72 \mathrm{~mL})$ at a rate to maintain reflux of the reaction mixture. When the addition was complete, the mixture was stirred for additional $1 \mathrm{~h}$ at $60{ }^{\circ} \mathrm{C}$, cooled to ambient temperature, and added dropwise to a stirred solution of diethyl chlorophosphate $(8.40 \mathrm{~g}, 48.68 \mathrm{mmol}, 7.00 \mathrm{~mL})$ in anhydrous THF $(20 \mathrm{~mL})$ at $0{ }^{\circ} \mathrm{C}$. The resultant mixture was stirred at ambient temperature for $1 \mathrm{~h}$, followed by $12 \mathrm{~h}$ at $60{ }^{\circ} \mathrm{C}$. It was then poured into an aqueous solution of $\mathrm{NH}_{4} \mathrm{Cl}$, and the organic layer was separated. The aqueous fraction was saturated with $\mathrm{NaCl}$, and the organic layer was separated. The combined organic fraction was dried $\left(\mathrm{MgSO}_{4}\right)$, the solvent removed under reduced pressure, and the residue passed through a short silica-gel column, which was eluted successively with hexane- $\mathrm{CH}_{2} \mathrm{Cl}_{2}=1: 1 \quad(400 \mathrm{~mL})$, hexane-EtOAc $=1: 3$ $(400 \mathrm{~mL})$, and EtOAc $(200 \mathrm{~mL})$. The second and third fractions were combined, and the solvent was removed under reduced pressure to yield the target as a colorless oil $(7.10 \mathrm{~g}, 60 \%) .{ }^{1} \mathrm{H}$ NMR $\left(\mathrm{CDCl}_{3}\right) \quad \delta \quad 1.32$ $(\mathrm{t}, J=7.5 \mathrm{~Hz}, 6 \mathrm{H}), 2.34(\mathrm{~s}, 3 \mathrm{H}), 2.52(\mathrm{~s}, 3 \mathrm{H}), 4.02-4.19(\mathrm{~m}, 4 \mathrm{H}), 7.14(\mathrm{dd}$, $\left.J_{1}=7.7 \mathrm{~Hz}, \quad J_{2}=5.9 \mathrm{~Hz}, 1 \mathrm{H}\right), 7.23 \quad(\mathrm{~d}, J=7.7 \mathrm{~Hz}, 1 \mathrm{H}), 7.75 \quad(\mathrm{dd}$, $\left.J_{1}=14.7 \mathrm{~Hz}, J_{2}=1.6 \mathrm{~Hz}, 1 \mathrm{H}\right) ;{ }^{13} \mathrm{C} \mathrm{NMR}\left(\mathrm{CDCl}_{3}\right) \delta 16.3(\mathrm{~d}, J=6.5 \mathrm{~Hz})$, $20.6(\mathrm{~d}, J=3.4 \mathrm{~Hz}), 20.7(\mathrm{~s}), 61.8(\mathrm{~d}, J=5.4 \mathrm{~Hz}), 126.4(\mathrm{~d}, J=182.6 \mathrm{~Hz})$, $131.1(\mathrm{~d}, J=15.8 \mathrm{~Hz}), 133.1(\mathrm{~d}, J=3.2 \mathrm{~Hz}), 134.5(\mathrm{~d}, J=10.5 \mathrm{~Hz}), 134.9$ $(\mathrm{d}, \quad J=15.0 \mathrm{~Hz}), 138.5(\mathrm{~d}, \quad J=9.9 \mathrm{~Hz}) ;{ }^{31} \mathrm{P}$ NMR (proton-decoupled) $\left(\mathrm{CDCl}_{3}\right) \delta 19.9(\mathrm{~s})$.

Method B

$t$-BuLi ( $10.80 \mathrm{mmol}, 6.36 \mathrm{~mL}$ of $1.7 \mathrm{M}$ soln. in pentane) was added dropwise to a solution of 2-bromo- $p$-xylene $(2.00 \mathrm{~g}, 10.80 \mathrm{mmol}, 1.50 \mathrm{~mL})$ in anhydrous 
THF $(10 \mathrm{~mL})$ at $-78{ }^{\circ} \mathrm{C}$ (dry ice-acetone) in inert atmosphere. The reaction mixture was stirred for one hour at $-78{ }^{\circ} \mathrm{C}$ then gradually warmed up to $0{ }^{\circ} \mathrm{C}$ over a $0.5 \mathrm{~h}$ period. The resultant solution was added dropwise to a solution of diethyl chlorophosphate $(1.86 \mathrm{~g}, 10.80 \mathrm{mmol}, 1.55 \mathrm{~mL})$ in anhydrous THF $(5 \mathrm{~mL})$ at $0{ }^{\circ} \mathrm{C}$, and stirring was continued for $12 \mathrm{~h}$ at ambient temperature. The resultant mixture was added to an aqueous solution of ammonium chloride $(2.00 \mathrm{~g}$ in $50 \mathrm{~mL}$ of water) followed by addition of ether $(50 \mathrm{~mL})$. After stirring for $5 \mathrm{~min}$, the layers were separated, the organic layer was dried $\left(\mathrm{MgSO}_{4}\right)$, and the solvent removed under reduced pressure. The crude product was further purified on a silica-gel column (hexane-ethyl acetate $=1: 1)$. The solvents were removed to yield the product as a clear oil $(2.05 \mathrm{~g}, 78 \%)$. Spectral data of the product were analogous to those reported under method $\mathrm{A}$.

\section{2-Phosphonoterephthalic Acid (2)}

A mixture of compound $6(5.40 \mathrm{~g}, 22.31 \mathrm{mmol})$, water $(90 \mathrm{~mL})$, and $t$-butanol $(10 \mathrm{~mL})$ was heated to reflux. Potassium permanganate $(14.00 \mathrm{~g}, 89.16 \mathrm{mmol})$ was added in small portions, and the mixture was left stirring at reflux for $2 \mathrm{~h}$. The temperature was then reduced to $80{ }^{\circ} \mathrm{C}$, and stirring continued for $12 \mathrm{~h}$. The mixture was then cooled to ambient temperature and vacuum filtered on a fritted funnel. The filtrate was concentrated under reduced pressure and then acidified with concentrated hydrochloric acid, while controlling the temperature with an ice bath. The mixture was kept for an additional $3 \mathrm{~h}$ at $0{ }^{\circ} \mathrm{C}$, and the resultant precipitate was vacuum filtered. It was then suspended in water $(10 \mathrm{~mL})$, heated to reflux, cooled, vacuum filtered, and dried to yield $3.33 \mathrm{~g}(61 \%)$ of white solid. Mp $295-297{ }^{\circ} \mathrm{C}$ (lit. ${ }^{[6,7]} 298{ }^{\circ} \mathrm{C}$, $\left.288-290{ }^{\circ} \mathrm{C}\right) .{ }^{1} \mathrm{H}$ NMR $\left(\mathrm{D}_{2} \mathrm{O}\right) \delta 7.67\left(\mathrm{dd}, J_{1}=8.0 \mathrm{~Hz}, J_{2}=4.0 \mathrm{~Hz}, 1 \mathrm{H}\right)$, $7.93\left(\mathrm{dt}, J_{1}=8.0 \mathrm{~Hz}, J_{2}=1.0 \mathrm{~Hz}, 1 \mathrm{H}\right), 8.27\left(\mathrm{dd}, J_{1}=15.0 \mathrm{~Hz}, J_{2}=1.0 \mathrm{~Hz}\right.$, $1 \mathrm{H}) ;{ }^{1} \mathrm{H}$ NMR (DMSO- $\left.d_{6}\right) \delta 7.87\left(\mathrm{dd}, J_{1}=8.1 \mathrm{~Hz}, J_{2}=4.8 \mathrm{~Hz}, 1 \mathrm{H}\right), 8.02$ $\left(\mathrm{dt}, J_{1}=8.1 \mathrm{~Hz}, J_{2}=1.5 \mathrm{~Hz}, 1 \mathrm{H}\right), 8.42\left(\mathrm{dd}, J_{1}=13.8 \mathrm{~Hz}, J_{2}=1.5 \mathrm{~Hz}, 1 \mathrm{H}\right)$; ${ }^{13} \mathrm{C}$ NMR (DMSO- $\left.d_{6}\right) \quad \delta \quad 130.8 \quad(\mathrm{~d}, \quad J=11.6 \mathrm{~Hz}), 131.5 \quad(\mathrm{~s}), \quad 132.3$ $(\mathrm{d}, J=12.5 \mathrm{~Hz}), 133.6(\mathrm{~d}, J=12.1 \mathrm{~Hz}), 135.9(\mathrm{~s}), 140.2(\mathrm{~d}, J=9.0 \mathrm{~Hz})$, $167.0(\mathrm{~s}), 169.4(\mathrm{~d}, J=5.0 \mathrm{~Hz}) ;{ }^{31} \mathrm{P}$ NMR (proton-decoupled) $\left(\mathrm{DMSO}-d_{6}\right) \delta$ 10.8 (s). Anal. calcd. for $\mathrm{C}_{8} \mathrm{H}_{7} \mathrm{O}_{7} \mathrm{P}: \mathrm{C}, 39.04 ; \mathrm{H}, 2.87$. Found: C, 39.31; $\mathrm{H}, 3.08$.

\section{ACKNOWLEDGMENTS}

Partial funding for this project was provided by a Challenge Grant from the Ohio Board of Regents. S. Branion thanks the University of Dayton Research Council for summer financial support. 


\section{REFERENCES}

1. Dang, T. D.; Arnold, F. E. Water-Soluble Rigid-Rod Polymers. U.S. Patent 5312876, 1994.

2. Spry, R. J.; Alexander, M. D. J.; Bai, S. J.; Dang, T. D.; Price, G. E.; Dean, D. R.; Kumar, B.; Solomon, J. S.; Arnold, F. E. J. Polymer Sci., Part B 1997, 35, 2925-2933.

3. Viale, S.; Li, N.; Schotman, A. H. M.; Best, A. M.; Picken, S. J. Macromolecules 2005, 38, 3647-3652.

4. Takeoka, S.; Hara, T.; Yamamoto, K.; Tsuchida, E. Chem. Lett. 1996, 253-254.

5. Jackson, P.; Tsukamoto, T.; Slusher, B.; Wang, E. Benzenedicarboxylic Acid Derivatives as NAALDase Inhibitors. PCT Int. Appl., WO 2001092273, 2001.

6. Suzuki, H.; Nomura, M.; Tokunaga, K.; Hashiba, I. Phenylphosphonic Acid Derivative and Production Process thereof. Eur. Pat. Appl. EP0855400, 1998.

7. Hashiba, I.; Tokunaga, K. Derivative of Phosphonic Acid and Process for its Preparation. Eur. Pat. Appl. EP842940, 1998.

8. Dyatkina, N. B.; Roberts, C. D.; Keicher, J. D.; Dai, Y.; Nadherny, J. P.; Zhang, W.; Schmitz, U.; Kongpachith, A.; Fung, K.; Novikov, A. A.; Lou, L.; Velligan, M.; Khorlin, A. A.; Chen, M. S. J. Med. Chem. 2002, 45, 805-817.

9. Nelson, P. H.; Untch, K. G. In Esters of 2-Substituted-5-oxo-5H-dibenzo[a,d] cycloheptenes having Pharmaceutical Activity, and Methods and Compositions for the Use thereof. US Patent 4112114, 1978.

10. Anzalone, L.; Hirsch, J. A. J. Org. Chem. 1985, 50, 2128-2133.

11. Lantzsch, R.; Marhold, A.; Lehment, K. F. Sulfonic Acids Ger. Offen. DE2545644, 1977.

12. Effenberger, E.; Kottmann, H. Tetrahedron 1985, 41, 4171-4182.

13. Kottmann, H.; Skarzewski, J.; Effenberger, E. Synthesis 1987, 797-801.

14. Burgoyne, E. E.; Klose, T. G.; Watson, D. K. J. Org. Chem. 1955, 20, 1508-1512. 